\section{Badly Equipped, Under-financed, Technologically Backward but Splendidly Uniformed: A Brief View into Austria- Hungary's Efforts in the Eastern Front and the Battle of Galicia}

\section{Jack Sweeney}

Sophomore, History

Introduction to the Eastern Front

It is widely accepted that there is a dearth of literature written on the Eastern Front. The first considerable book on the topic was written by Scottish historian, Norman Stone, and still stands as a landmark in the historiography in the First World War. Many of the authors whose works are used as sources in this paper can be found agreeing with the first sentence. While there are many reasons contributing to the lack of literature, it is mostly due to governmental control of sources pertaining to the First World War. As a result, stories and various works dedicated to the Eastern Front are finally beginning to see the light they truly deserve in the present day.

With that being stated, it is shameful that historians have not been as exposed to the Eastern Front as the Western Front. A world of its own, separate from the battles of the Somme and Verdun, formed as the desperate struggle for Eastern Europe waged on until 1917. The substance of the war is so particularly interesting because of the parties involved. On one side, the ancient Hapsburgs, which had not seen a major war in over 40 years, were forced into the conflict by the assassinations of Archduke Franz Ferdinand and his wife Sophie. On the other side, the Romanov family that controlled Russia was apt to mobilize its huge and cluttered armies against the German Hohenzollerns and the Hapsburgs. Whatever long term effects this war had on the world and especially Europe, the useless and unending violence seen during those first three years as the war began has had a likewise impact.

This paper will be aimed at focusing in on Austria-Hungary's role in the first three years of the war. Especially analyzing what was occurring in Austria-Hungary leading up to the conflict, and who led the colossal armies. A deep analysis of the Battle of Galicia, with minor descriptions of the Gorlice-Tarnow campaign, and the Brusilov offensive, will also be present. In order of importance and impact, the Battle of Galicia destroyed the morale and much of the regular army of the Hapsburgs, while the Brusilov offensive destroyed the rest of the soldiers who had not yet seen heavy combat, and the Gorlice- Tarnow campaign proved that the man power of the Hapsburgs was best harnessed with Germany's tentative armies and leadership. Austria-Hungary was not successful on the Eastern Front on its own in any significant way due to their lack of modernity, the rank and file of the army, technology, and government. This is proven directly in the poor results of combat seen in the Battle of Galicia, and the all-but-stellar leadership of Baron Conrad von Hötzendorf. 
Background on the Dual Monarchy

Since the rise of the Hapsburgs in the $13^{\text {th }}$ century, their strong suit in expanding influence was typically through marriage, not military involvement. The Latin phrase "Bella gerant alii, tu felix Austria nube!" translates into "Let others wage war; you, happy Austria, marry!" Though, as the Hapsburgs secured the Holy Roman Crown, they were the foremost authority in defending Europe from the Ottoman Empire. Therefore, they did know how to fight, but preferred to expand through diplomacy. After Napoleon disbanded the Holy Roman Empire in 1806, the Hapsburg family was then located to Austria. After their defeat by Prussia in 1866, they decided to stop looking north but instead east and south, which can be inadvertently attributed to the start of the war. $^{2}$

Although their territory wasn't nearly as large as the behemoth empires of France or England, the ethnic diversity of the empire was impressive. Austria-Hungary found itself in control of almost more than it could rule. John R. Schlinder's Fall of the Double Eagle: The Battle for Galicia and the Demise of Austria-Hungary serves as a great resource to analyze what the Hapsburgs had on their hands: "The 1910 census showed a population of thirty million, consisting of ten ethnic groups, the biggest being Germans (36 percent), Czechs (23 percent), Poles (18 percent), and Ukrainians (13 percent)." ${ }^{\prime 3}$ Not to mention, the governmental system it found itself in. It was a dual monarchy, unique at the time, that consisted of the Austrian Emperor and the Hungarian King. Their agreement in 1867 after the Hapsburg defeat by Prussia was an attempt to placate Hungary by giving it semi-autonomy. ${ }^{4}$

Other than the Balkan Crisis of 1908, Austro-Hungary was not involved in any major conflicts. Therefore, while Russia fought against the Ottomans and Japan, or while Germany fought France, the Hapsburgs flaunted their glamorous and colorful armies in annual military pageants. ${ }^{5}$ All the different cultures brought forth many different kinds of military uniforms, a symbol of the hectic landscape the Hapsburgs lived in. ${ }^{6}$ Further forcing the Hapsburgs into military obscurity, the long-lived emperor, Franz Joseph, did not embrace the modern technology and tactics that other European powers obsessed about. The Austro-Hungarian empire had the lowest conscription rates of any major European power, even lacking behind Italy. ${ }^{7}$ Instead, Franz Joseph lived the life of a traditional soldier, and made sure his armies were traditional. The title of the paper is a quote from Alan Sked's assessment of the Hapsburg army. ${ }^{8}$ So, when the heir was assassinated in 1914, the empire's lack of recent military conflicts was a possible reason the Hapsburgs waited so long to declare war on Serbia.

The Players and "Conradian Concepts"

Leading the Austro-Hungarians in 1914, although nominally, were Archduke Frederick and Emperor Franz Joseph. They 
appointed Conrad von Hötzendorf as chief of the general staff, who proved to be not a man of his time, but a man of his place.

Conrad was a man of his place in the sense that his tactics as commander were similar to the tactics used in the mid- $19^{\text {th }}$ century. Totally unfit to lead the army, Conrad is partially responsible for the defeats at Galicia and during the Brusilov Offensive. Although he did in some ways try to modernize the armies of the dual monarchy, he was not successful in any way. Any attempt to call for an increase in funding for the military would be curtailed by Franz Joseph. Conrad led an old, albeit feisty, $19^{\text {th }}$ century army against Russia; his army received the fate one would suspect.

Seen from an outside point of view, one would call Conrad a buffoon. But as previously mentioned, he was a man of his place, and was used to controlling an army of outdated soldiers. Additionally, John R. Schlinder's term for Conrad's thought process, "Conradian Concepts,", can show be used to analyze his thought process. Conrad would believe in his military to the point of absurdity, and would get offended and surprised when they lose in battle. His personality was something out of a fantasy book. Brooding at most times, he would go into most situations with a sort of pessimistic pride in his troops.

The Battle of Galicia... (or the Snap of the Hapsburg Spine)

After Conrad had decided it was best to attack Serbia before Russia, and create a two-front war, the offensive with Russia began in August. It is possible that if Austria-Hungary had diverted all of its resources to battling Russia instead of punishing Serbia, the outcome of this battle would be different. This entire campaign can be characterized as the chapter header in Stuart Robson's The First World War, "Badly Planned Disasters." "Despite the moronic planning, the armies of

Austria-Hungary were all united and ready to be deployed. All ethnicities, no matter their past, for the most part seemed to link together in this struggle against Russia and to punish the Serbs. Even the unruliest of the ethnic minorities settled and sent their men to fight the enemy. This is a common theme in the war, on both fronts: settling differences to fight for a common cause.

After the armies mobilized for battle, the process of getting to the front was just another byproduct of the dated empire. Their transportation, which stemmed from locomotion, chugged slower than Russia's, and after their destination was reached, the out-of-shape soldiers marched straight to the front for miles. Fighting exhaustion, the zeal for to serve for the emperor seemed to keep things going for everyone. Once the army got where they needed to be, the real problem was to find Russia.

Austria-Hungary also had to declare where they wanted the front to be. For a few days reconnaissance proved to be insufficient on both sides, but eventually, Austro-Hungarian cavalry found what they were looking for. When the first cavalry men charged on Russian lines, they were ripped apart by machine gun fire. Soon enough, everyone 
just went into battle, including the prestigious White Dragoons, including Conrad's beloved son Herbert, "charged into battle in full dress uniforms as if the twentieth century had not begun, led by their commander yelling hurrá as Russian artillery rounds exploded above them." 11 Herbert would die during this first two weeks of fighting.

The valor and bravery shown by the soldiers those first two weeks bordered on insanity. Despite the outmoded weaponry and heavy casualties, the armies of the Hapsburgs were still able to confirm a few initial victories, although not for long. Even other inferior Russian commanders were able to beat back and outmaneuver most of the Hapsburg troops, with more modern tactics and weapons. Another advantage the Russians had over the Austro-Hungarians were their uniforms. The drab color of the standard soldier made them hard to spot, while the vibrant yellow sashes of Austro-Hungarian officers served as target practice. The army that had not seen war in over 40 years had now been put to the test, and to make matters worse, the esteemed General Aleksei Brusilov made his way towards the city of Lemberg.

The tactics of the Austro-Hungarians in battle were equally shocking. Fueled by their pride and fatalism, nothing would stop lines of soldiers from running straight into machine gun fire or artillery. Looking at the Russian tactics at Tannenberg, it looked like the Hapsburgs were beating Russia at their own game of 'steamrolling.' But, Russia had a steamroller of their own, one backed with a surfeit of soldiers. The country with the lowest conscription rate was dying as fast as the Russians were, but with worse long-term effects. The various victories seen in the earliest of fighting were not strategic victories in any manner. Russia would retreat to eventually come back and overwhelm any of the land lost. Although Russia had also taken heavy losses, there now came a time where the manpower of the Austro-Hungarians was insufficient. Especially seen during the Lemberg portion of the campaign, order had broken down as most of the people in control fled or were killed in battle. Brusilov captured Lemberg with little resistance. At this point, Conrad could have done anything, like question prisoners, listen into Russian commands like the Germans had, or set a strategic position to take, but he did not want to focus on the fact Austria-Hungary was losing. He ordered the battered and bruised soldiers that remained to give the Russians everything they had. Like in the aftermath of the siege of Acre in the First Crusade, the Russians, like the Christian knights, were too weak to defend from the Austro-Hungarian 'steamroller,' so they opted to attack. Austria-Hungary was in a similar state, but superior Russian tactics and technology bested them. What resulted was the final nail in the coffin. The "great retreat" saw the exodus of any Hapsburg soldier that could make it back before the San river. Many who had been too exhausted to run were captured, resulting in one of the worst badly planned disasters of the First World War. 
In just three weeks, Conrad had destroyed his army. To prevent the people on the home front from finding out, the army sent this letter out to officers: "When officers and military officials criticize our war leadership, and the public hears this, the consequences can be most unfavorable ... Therefore, all military personnel (including the wounded) are instructed to urgently refrain from any unauthorized disclosure of their combat... Violations of this order will be punished in the most severe manner." ${ }^{12}$ What had occurred after the battle, the aftermath, was a completely altered perception on the war. The thoughts of being home by Christmas were no longer prevalent, and most of the casualties from Galicia had an immense impact on the soldiers who had watched their brothers and comrades die. The various ethnicities, once bonded together in the struggle against Russia, started blaming each other in a vicious cycle. Conrad even went as far as to blame Germany, despite the fact he had not requested any sort of aid before poking the Russian hornet nest. If this was a defeat, it was a defeat on a catastrophic level, that broke the morale of Austria-Hungary. Nothing in the history of the Hapsburgs had compared to the loss of Galicia. They would not fully recover from this, and would solely rely on Germany as the war pressed on.

\section{The Gorlice-Tarnow Campaign (or} Germany's Brilliance)

After the events in Galicia, panic spread throughout Vienna and Budapest. Too prevent the empire from collapsing, Berlin sent the great minds of Ludendorff and Hindenburg to help. "Thereupon the time had come to crush the enemy in a common attack with the full force of the combined troops of both empires." ${ }^{\prime 13}$ After seeing the army of Austria-Hungary crushed, Germany knew that in the aftermath they must take the lead against Russia. After getting their forces together in the fall of 1914, the

Austro-Hungarian/German coalition decided to try their luck to regain the territory lost just months prior. The outbreak of the war saw Germany's loss of countless troops on both fronts, and as explained in the last section, the Hapsburgs were in even worse condition.

Both Central Power armies had faced these individual problems on the Eastern Front. "To master these problems, close cooperation between Germany and Austria-Hungary was required. The outcome of this effort ... would depend to a great degree on the personal relationship between the respective military chiefs..." ${ }^{\prime 14}$ Although Conrad would remain in charge of the Austro-Hungarian armies, the actions of Conrad were well known by the masterminds of the German eastern front, Ludendorff and Hindenburg. Richard L.

DiNardo's Breakthrough: the Gorlice-Tarnow Campaign, 1915 claims that the outcome of the offensive rested only on the commanders of the coalition and the German army. ${ }^{15}$ Both armies mobilized their troops and the offense started in May 1915.

Through iron German precision and valor, the coalition was successful in breaking the back of polish-occupied Russia, 
albeit temporarily. A report written by Austrian Field Marshal Krobatin proudly sums up the results:

A victory at Tarnow and Gorlice freed West Galicia from the enemy and caused the Russian fronts on the Nida and in the Carpathians to give way. In a ten days' battle the victorious troops beat the Russian third and eighth armies to annihilation, and quickly covered the ground from the Dunajec and Beskids to the San river- 130 kilometers (nearly 81 miles) of territory. ${ }^{16}$

While there were some victories claimed by the Hapsburg armies, if it was not for the aid of Germany, the recapture of Lemberg would be impossible. Austria-Hungary's armies would rejoice in this victory, and consequently, they would get lazy and proud. On the other side of the battlefield, a most able commander twirled his moustache and conspired to take back what Russia had lost.

The Brusilov Offensive... (or Putting the Dog to Sleep)

Like the Gorlice-Tarnow campaign was a reaction to the gains Russia made after Austria-Hungary's horrific defeat in Galicia, the Brusilov Offensive was reactionary to the Gorlice-Tarnow campaign. To sweeten the deal for the allies, if Russia could have somehow (although they expected very little) threatened Germany enough to send troops back to Eastern front away from Verdun, that would be helpful for everyone.
General Aleksei Brusilov decided it was time for a new Russian offensive, so he began planning with the Russian war council. Although he remained obedient to the Tsar, Brusilov was typically aware of the qualities of his associate generals. So, he independently decided to plan to distract the German armies of the Eastern front long enough to hit the Hapsburgs as hard as possible.

The areas defended by the Hapsburgs were a series of trenches that seemed to have finally caught up to the times they were in. Unfortunately for Austro-Hungary, the great losses of men from the two past years had put a strain on the already lacking army. "The Hapsburg government passed extraordinary measures to make up the sheer number, allowing Gypsies to serve, extending the age span for military service from 19-42 to $18-50$, and recalling the 2.3 million men who had been deemed unfit for duty in the previous decade." $" 17$ Additionally, Conradian Concepts of superiority led to the lessening of soldiers on the Galician front so more troops could buttress the new front in Italy. Conrad was confident enough to basically put the forces of Brusilov in a better position to attack than ever. In fact, as noted in Timothy C. Dowling's The Brusilov Offensive, most of the troops on the reclaimed Galician front had never actually been in real combat, and the little training they did was instead substituted for snow shoveling. ${ }^{18}$ In June 1916, it was finally made evident why history does not call this offensive a great 
Hapsburg victory. Even if Brusilov brought only a simple style of command to his part of the front, it was effect enough to annihilate the Hapsburg presence in Galicia. It was only the counter-effort of the Germans that halted the blazing attack. In the aftermath, one could finally say Austro-Hungary was reduced to German vassalage. Vienna would cease to function without the life support of Berlin, and things would get worse until Russia withdrew from the war in 1917.

Conclusion: Why We Don't Talk About Austria-Hungary

When the amalgamation of Germans, Hungarians, Croats, Serbs, Czechs, Poles, Ukrainians, Bosnians, Romanians, and Italians banded together in the name of the emperor to fight the scourge of Russia, none could have expected the results. So typical is it of an old empire to reject the future and instead bask in the drug of nostalgia. Apart from the assassination of Franz Ferdinand, the magnitude of discussion, remembrance, and respects to the late empire are not very common in America, or as it seems much of else of the western world. This is due to many reasons, possibly because Germany's accomplishments in the war, or because of the mediocre role Austria-Hungary would come to play as the war unfolded. The loss at Galicia should be more widely known, as no slaughter of that kind was seen until the First World War. In conclusion, while there were many reasons contributing to the poor quality of the Habsburg military, the loss of life and strategic failures were due to the wavering leadership of Conrad von
Hötzendorf and the brutal might of the Russian military. 


\section{NOTES}

${ }^{1}$ John R. Schinder, Fall of the Double Eagle: The Battle for Galicia and the Demise of Austria-Hungary (Potomac, 2015), 13.

${ }^{2}$ Schinder, Fall of the Double Eagle, 16.

${ }^{3}$ Schinder, Fall of the Double Eagle, 19.

${ }^{4}$ Schinder, Fall of the Double Eagle, 15.

${ }^{5}$ See Appendix 1

${ }^{6}$ See Appendix 2

${ }^{7}$ Schinder, Fall of the Double Eagle, 38.

${ }^{8}$ Schinder, Fall of the Double Eagle, 40.

${ }^{9}$ Schinder, Fall of the Double Eagle, 153.

${ }^{10}$ Stuart Robson, The First World War, (Pearson, 2007), 29.

${ }^{11}$ Schinder, Fall of the Double Eagle, 168

${ }^{12}$ Schinder, Fall of the Double Eagle, 211.

${ }^{13}$ Charles F. Horne, The Great Events of the Great War: Volume III A.D. 1915, (The National Alumni, 1920), 182-183.

${ }^{14}$ Richard L. DiNardo, Breakthrough: the Gorlice-Tarnow Campaign, 1915, (Praeger, 2010), 17.

${ }^{15}$ DiNardo, Breakthrough, 31.

${ }^{16}$ Horne, The Great Events of the Great War, 182.

${ }^{17}$ Timothy C. Dowling, The Brusilov Offensive, (Bloomington: Indiana University Press, 2008), 24.

${ }^{18}$ Dowling, The Brusilov Offensive, 56. 


\section{APPENDICES}

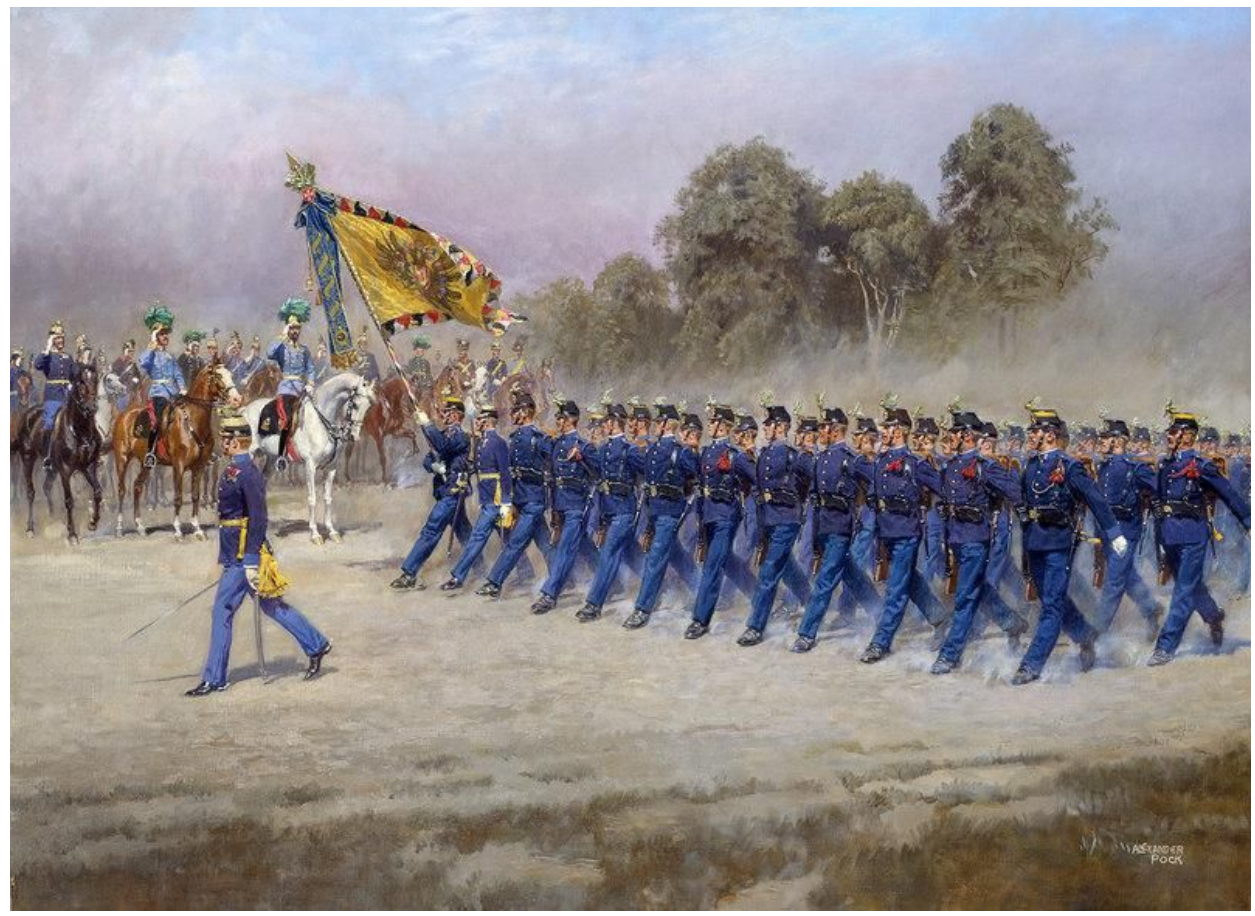

Appendix 1

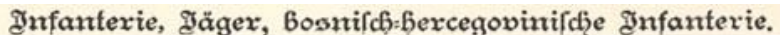

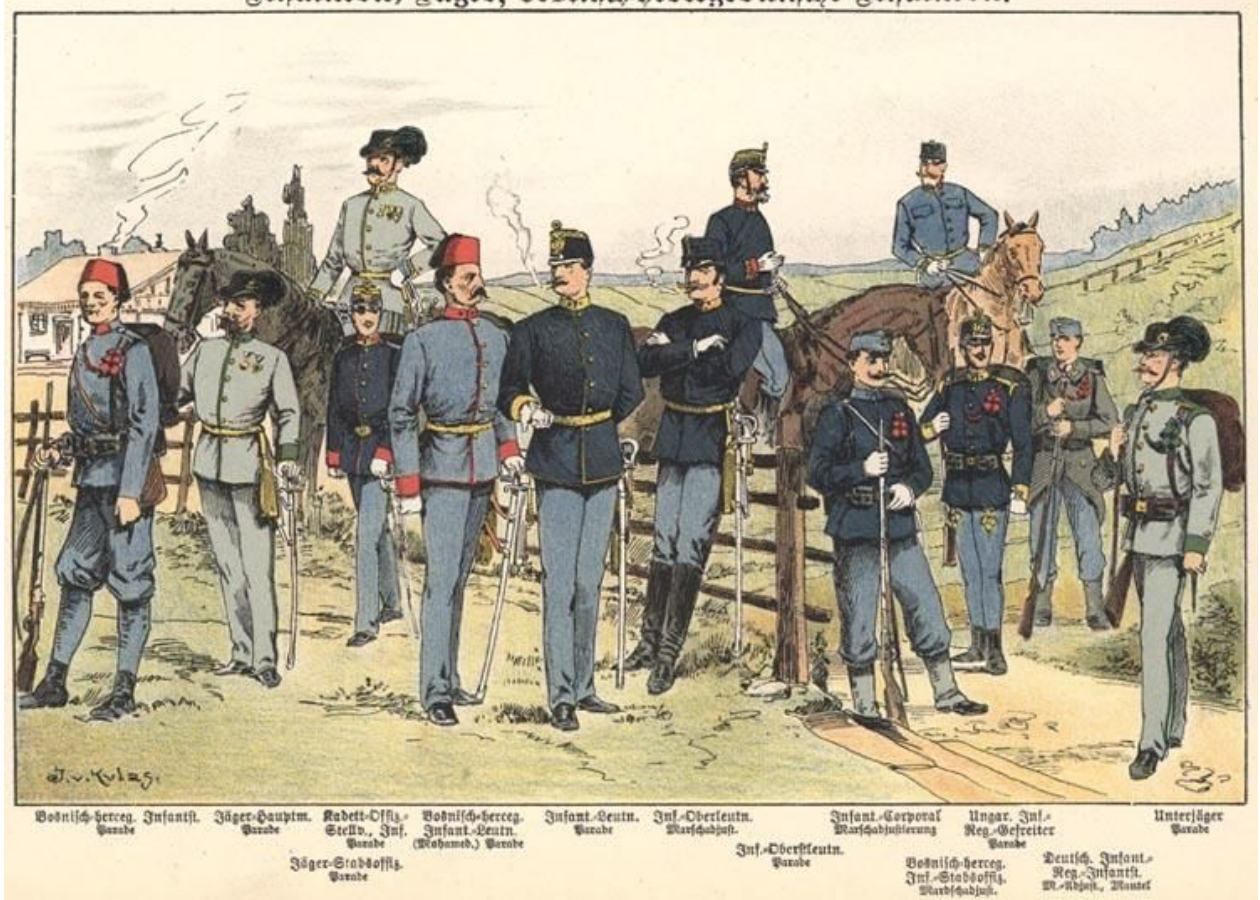

Appendix 2 